\title{
Optimization of Culture Conditions for Production of Amylase by Bacillus amyloliquifaciens SH8 Using Response Surface Methodology
}

\author{
SHRUTI PATHANIA*, NIVEDITA SHARMA and SHWETA HANDA \\ Dr Y S Parmar University of Horticulture and Forestry, Nauni, Solan 173 230, HP, India
}

(Received on 21 April 2016; Revised on 20 July 2016; Accepted on 28 September 2016)

\begin{abstract}
In the present study Response surface methodology (RSM) was used to investigate the combined effect of relevant process variables to enhance the production of amylase under submerged fermentation by Bacillus amyloliquifaciens SH8. The process variables included $\mathrm{pH}$, temperature, inoculum size, incubation days and substrate concentration. A 54 factorial central composite design (CCD) using response surface methodology (RSM) was employed to obtain interaction between the process variables and optimizing amylase titers. Total 54 experiments were carried out in shake flask and a three dimensional response surface was generated to determine the effect of process variables on amylase production. The optimal calculated values of tested variables for maximal production of amylase were: $\mathrm{pH} 5$, temperature $45^{\circ} \mathrm{C}$, inoculum size $5 \%$, incubation day of 5 and substrate concentration of $0.60 \%$ with $16.07 \mathrm{IU} / \mathrm{ml}$ of amylase activity
\end{abstract}

Keywords: Amylase; Bacillus amyloliquifaciens SH8; Submerged Fermentation; Response Surface Methodology

\section{Introduction}

Starch, a homo-polysaccharideisan important and abundant food reserve and energy source in plants.It is found in seeds, fruits, leaves, bulbs and tubers (Bozic et al., 2011). Structurally it is a composite polymer of amylose and amylopectin which varies in proportion depending on its source. The $\alpha$-amylase family comprises a group of enzymes with a variety of different specificities that all act on one type of substrate being glucose residues linked through a $\alpha$ $1-1, \alpha-1-4, \alpha-1-6$, glycosidic bonds. Members of this family share a number of common characteristics (Van der Maarel et al., 2002). Amylases can be divided into two categories, endoamylases and exoamylases. Endoamylases catalyze hydrolysis in a random manner in the interior of the starch molecule producing linear and branched oligosaccharides of various chain lengths. Exoamylases act from the nonreducing end successively resulting in short end products (Gupta et al., 2003). Although they can be derived from a variety of sources such as plants, animals and microorganisms, microbial enzymes are generally used to meet the industrial demands. The performance, economics and feasibility of each $\alpha$ amylase applications is influenced by important enzyme characteristics, including specificity, stability, optimum temperature and $\mathrm{pH}$ performance (Gupta et al., 2003). Therefore, selection of the suitable microbial strains which produce enzymes that's how good activity and stability at industrially desirable conditions will be valuable. Generally, the microbial production of $\alpha$-amylase is greatly influenced by the components of the culture medium,especially the carbon and nitrogen sources and physical conditions, such as the $\mathrm{pH}$, temperature, agitation, level of dissolved oxygen and the inoculum concentration (Rezaei et al., 2010).

Several models for amylase action pattern have been proposed, such as the random action and the multiple attack action. Random action has also been referred to as a single attack or multi-chain attack action (Azhari \& Lotan, 1991). In short, it can clearly be seen that the multiple attack action is generally an accepted concept to explain the differences in action pattern of amylases (Kramhøft et al. 2005; Svensson et al., 2002; Bijttebier et al. (2008) showed that the

*Author for Correspondence: E-mail: shrutipathania89@gmail.com 
level of multiple attack of several end amylases increased with temperature to a degree depending on the amylase. Submerged fermentation is the cultivation of the microorganism in a liquid medium containing soluble carbon source and nutrients maintained under agitation. The use of the submerged culture is advantageous because of the ease of sterilization and process control rendering it easier to engineer in these systems. Depending on the strain and the culture conditions, the enzyme can be constitutive or inducible in the manner of production the latter, however, is a preferable method for enzyme production from bacterial fermentations (Vidhayalakshni et al., 2009).

In the present study optimization of various process parameters were done under submerged fermentation by response surface methodology for enhanced amylase production.

\section{Materials and Methods}

\section{Microorganism and Culture Condition}

B. amyloliquifaciens SH8 was isolated from the compost sample. It was maintained on nutrient agar medium and stored at $4{ }^{\circ} \mathrm{C}$. Seed culture was developed by inoculating nutrient broth of $B$ .amyloliquifaciens $\mathrm{SH} 8$ into $50 \mathrm{ml}$ of production medium Starch $4 \mathrm{~g},\left(\mathrm{NH}_{4}\right)_{2} \mathrm{HSO}_{4} 0.5 \mathrm{~g}$, Yeast extract $0.5 \mathrm{~g}$; sodium citrate $0.2 ; \mathrm{Mg}_{2} \mathrm{SO}_{4} 0.05 ; \mathrm{CaCl}_{2} 0.08 \mathrm{~g}$; DW $1000 \mathrm{ml}$ of same composition were inoculated with $2 \mathrm{ml}$ of seed culture and grown for 5 days. Samples were withdrawn after 5 days and centrifuged at $10,000 \mathrm{rpm}$ for $10 \mathrm{~min}$ at $4^{\circ} \mathrm{C}$. Supernatant was used for analysis of starch activity.

\section{Enzyme Assay}

Quantitative Assay: Starch Hydrolysis (Shaw et al., 1995): Starch hydrolysis test was performed on amylase medium and incubated at $45^{\circ} \mathrm{C}$ for $72 \mathrm{~h}$. The size of zone of hydrolysis was measured.

Qualitative Assay: The enzyme assay was performed to quantify amylase (Xiao et al., 2006).

$0.5 \mathrm{ml}$ of enzyme solution was incubated with $0.2 \%$ starch at $37^{\circ} \mathrm{C}$ for $15 \mathrm{~min} .3 \mathrm{ml}$ of DNSA reagent was added to it and the mixture was heated on boiling water bath for $15 \mathrm{~min}$. After cooling down to room temperature, absorbance of reaction mixture was read at $540 \mathrm{~nm}$. The standard curve was made from the stock solution of glucose $(0.4 \mathrm{mg} / \mathrm{ml})$. One International unit of enzyme activity was defined as the amount of enzyme, releasing $1 \mathrm{~mol}$ of reducing group per minute per ml.

\section{Optimization of Amylase Production Using Response Surface Methodology}

Four experimental factors ( $\mathrm{pH}$ temperature, inoculum size, incubation days, substrate concentration) were found to have significant effect on amylase production. RSM using a three level central composite design was applied to optimize the response of four variables. A 54 factorial design was used in order to study the effect of $\mathrm{pH}$, temperature, inoculum size (\%), incubation day (days) and substrate concentration (\%). Preliminary experiments revealed that optimum incubation time for amylase production was 5 days. Therefore, enzyme activity after 5 days of production was measured as responses. The statistical analysis of the results was performed using Design Expert ver. 6.0.9 statistical software (Stat-Ease Inc, Minneapolis, MN). Amylase activity was analyzed using the analysis of variance (ANOVA) combined with the Fischer test to evaluate if a given term has a significant effect $(\geq 0.05)$. The optimum levels of the variables were obtained by graphical and numerical analysis using Design Expert program.

\section{Result and Discussion}

In the present work the isolate used was isolated from the compost and showed potential amylase production on starch agar plate with a zone of hydrolysis. The clear zone of hydrolysis around the bacterial colony is due to hydrolysis of starch by amylolytic enzyme (Fig. 1). It was identified by $16 \mathrm{~s}$ rRNAas $B$. Amyloliquefaciens SH8 with accession number from NCBI |JX129360.1|.

\section{Optimization of Culture Conditions by Central Composite Design}

Temperature, $\mathrm{pH}$, agitation speed, and substrate concentrations were chosen as the process parameters to optimize the conditions for maximum amylase production by a statistical design (CCD and RSM). A CCD with three coded levels for all the four factors $\mathrm{pH}(\mathrm{A})$, temperature (B), agitation speed (C) and starch concentration (D) were used for this purpose. The levels of parameters for the CCD were 


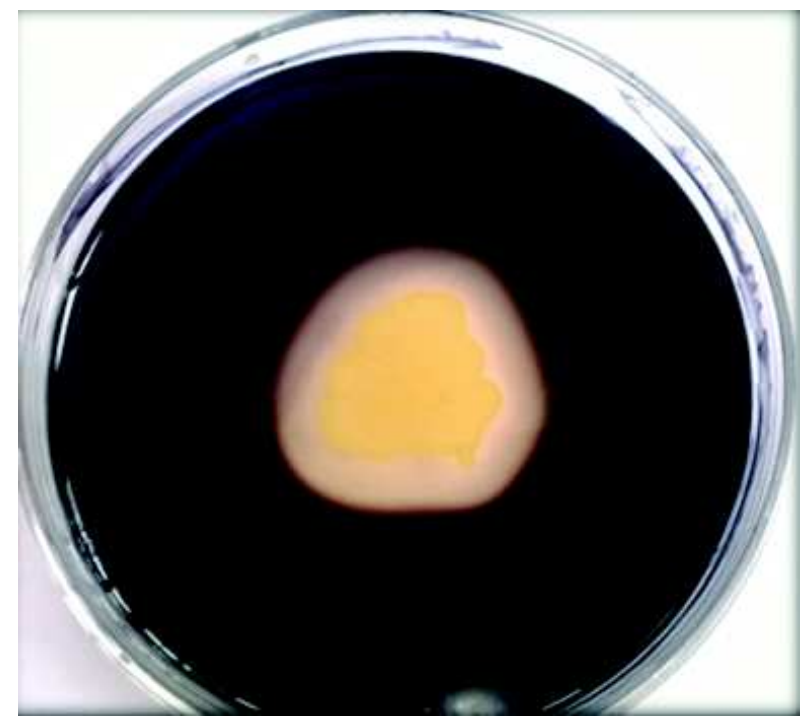

Fig. 1: Amylase production on starch agar plate by $B$. amyloliquifaciens SH8 after flooding with iodine

Table 1:

\begin{tabular}{lcccc}
\hline Factors & Unit & Symbols & \multicolumn{2}{c}{$\begin{array}{c}\text { Actual levels of } \\
\text { coded factors }\end{array}$} \\
\hline & & & -1 & +1 \\
$\mathrm{pH}$ & - & $\mathrm{A}$ & 5 & 8 \\
Temperature & ${ }^{\circ} \mathrm{C}$ & $\mathrm{B}$ & 30 & 45 \\
Inoculum size & $\%$ & $\mathrm{C}$ & 5 & 15 \\
Incubation days & Days & $\mathrm{D}$ & 3 & 7 \\
Substrate concentration & $\%$ & $\mathrm{E}$ & 0.2 & 0.6 \\
\hline
\end{tabular}

Table 2:

\begin{tabular}{lcccccc}
\hline Run & pH & $\begin{array}{c}\text { Tempera- } \\
\text { ture }\end{array}$ & $\begin{array}{c}\text { Inoculum } \\
\text { size }\end{array}$ & $\begin{array}{c}\text { Incuba- } \\
\text { tion } \\
\text { days }\end{array}$ & $\begin{array}{c}\text { Subs- } \\
\text { trate } \\
\text { concen- } \\
\text { tration }\end{array}$ & $\begin{array}{c}\text { Amylase } \\
\text { activity } \\
\text { (IU/ml) }\end{array}$ \\
\hline 1 & 6.5 & 37.50 & 10 & 5 & 0.40 & 8.66 \\
2 & 8.00 & 45 & 15 & 3 & 0.60 & 6.11 \\
3 & 5.00 & 45 & 5 & 7 & 0.20 & 10.43 \\
4 & 6.50 & 37.50 & 10 & 5 & 0.40 & 8.77 \\
5 & 6.50 & 37.50 & 10 & 5 & 0.40 & 7.66 \\
6 & 8.00 & 30 & 5 & 7 & 0.20 & 5.66 \\
7 & 8.00 & 45 & 5 & 7 & 0.60 & 6.73 \\
8 & 5.00 & 30 & 5 & 3 & 0.20 & 9.82 \\
9 & 5.00 & 30 & 5 & 7 & 0.60 & 10.2 \\
10 & 8.00 & 45 & 5 & 3 & 0.20 & 6.12 \\
11 & 5.00 & 45 & 5 & 3 & 0.60 & 11 \\
\hline
\end{tabular}

\begin{tabular}{|c|c|c|c|c|c|c|}
\hline 12 & 5.00 & 30 & 15 & 7 & 0.60 & 9.11 \\
\hline 13 & 8.00 & 45 & '15 & 3 & 0.20 & 5.77 \\
\hline 14 & 8.00 & 30 & 5 & 3 & 0.60 & 5.85 \\
\hline 15 & 5.00 & 45 & 15 & 7 & 0.60 & 10.18 \\
\hline 16 & 6.50 & 37.50 & 10 & 5 & 0.40 & 7.99 \\
\hline 17 & 8.00 & 30 & 15 & 3 & 0.20 & 5.22 \\
\hline 18 & 6.50 & 30 & 10 & 7.00 & 0.60 & 5.83 \\
\hline 19 & 8 & 30 & 15 & 3.00 & 0.20 & 10.03 \\
\hline 20 & 5 & 45 & 15 & 7.00 & 0.60 & 10.01 \\
\hline 21 & 5 & 30 & 15 & 3.00 & 0.20 & 6.43 \\
\hline 22 & 5 & 45 & 5 & 7.00 & 0.20 & 4.09 \\
\hline 23 & 8 & 45 & 5 & 7.00 & 0.20 & 10.32 \\
\hline 24 & 5 & 45 & 15 & 5.00 & 0.40 & 8.22 \\
\hline 25 & 6.50 & 37.50 & 10 & 7.00 & 0.60 & 6.55 \\
\hline 26 & 8.00 & 30 & 5 & 3.00 & 0.60 & 9.5 \\
\hline 27 & 5.00 & 45 & 15 & 3.00 & 0.60 & 4.32 \\
\hline 28 & 8.00 & 30 & 15 & 7.00 & 0.60 & 10.21 \\
\hline 29 & 5.00 & 30 & 5 & 3.00 & 0.60 & 6.99 \\
\hline 30 & 8.00 & 45 & 15 & 3.00 & 0.60 & 6.12 \\
\hline 31 & 8.00 & 45 & 10 & 5.00 & 0.40 & 8.97 \\
\hline 32 & 6.50 & 37.50 & 15 & 3.00 & 0.20 & 9.93 \\
\hline 33 & 5.00 & 30 & 5 & 3.00 & 0.60 & 10.50 \\
\hline 34 & 5.00 & 30 & 5 & 7.00 & 0.60 & 6.41 \\
\hline 35 & 8.00 & 45 & 15 & 5.00 & 0.40 & 8.7 \\
\hline 36 & 5.00 & 45.50 & 5 & 5.00 & 0.60 & 16.07 \\
\hline 37 & 5.00 & 37.50 & 15 & 5.00 & 0.40 & 8.94 \\
\hline 38 & 6.50 & 37.50 & 10 & 5 & 0.40 & 8.94 \\
\hline 39 & 8.00 & 37.50 & 10 & 5 & 0.60 & 12.92 \\
\hline 40 & 8.00 & 30 & 5 & 3 & 0.40 & 8.94 \\
\hline 41 & 6.50 & 30 & 15 & 7 & 0.20 & 5.44 \\
\hline 42 & 6.50 & 37.50 & 21.89 & 5 & 0.20 & 5.22 \\
\hline 43 & 6.50 & 55.34 & 10 & 5 & 0.40 & 7.48 \\
\hline 44 & 6.50 & 37.50 & 10 & 9.76 & 0.40 & 8.17 \\
\hline 45 & 6.50 & 37.50 & 10 & 5 & 0.40 & 8.28 \\
\hline 46 & 10.0 & 37.50 & 10 & 5 & 0.40 & 8.28 \\
\hline 47 & 6.50 & 37.50 & 10 & 5 & 0.40 & 7.69 \\
\hline 48 & 6.50 & 37.50 & 10 & 5 & 0.40 & 2.11 \\
\hline 49 & 6.50 & 19.66 & 10 & 5 & -0.08 & 6.71 \\
\hline 50 & 6.50 & 37.50 & 10 & 5 & 0.40 & 6.55 \\
\hline 51 & 6.50 & 37.50 & -1.89 & 5 & 0.88 & 7.66 \\
\hline 52 & 6.50 & 37.50 & 10 & 0.24 & 0.40 & 7.1 \\
\hline 53 & 2.93 & 37.50 & 10 & 5 & 0.40 & 11.94 \\
\hline 54 & 6.50 & 37.50 & 10 & 5 & 0.40 & 8.90 \\
\hline
\end{tabular}


based on preliminary experimental results and are represented in Table 1.

The central composite design and the results of the CCD obtained for amylase production are presented in Table 2.

\section{Validation of the Experimental Model}

Validation of the predicted results was accomplished by performing additional experiments in triplicate with the parameters suggested by the numerical modeling (suggested solution). These three sets of experiments yielded an average enzyme production of $16.07 \mathrm{IU} /$ $\mathrm{ml}$ at $\mathrm{pH} 5$, temperature $45^{\circ} \mathrm{C}$, inoculum size $5 \%$, after 5 days of incubation days and $0.60 \%$ of substrate concentration i.e. starch. Good agreement between the predicted and experimental results confirmed the experimental adequacy of the model and the existence of the optimal point. The regression model was drawn to illustrate the combined effects of the independent variables and combined effects of each independent variable upon the response variable. The response surface describing the quadratic effect of $\mathrm{pH}$ and temperature on xylanase production by Bacillus amyloliquifaciens SH8 is shown in Fig. 1a,b,c,d,e,f,g,h.

In case of amylase production from $B$. amyloliquifaciens, of all the parameters $\mathrm{pH}$ and incubation time exerted the most significant effect. The amylase model showed $\mathrm{F}$ value corresponding to 1.19 indicating the significance of the model with $\mathrm{p}$ value of $<0.05$ (Table 3 ). The lower value of $\mathrm{CV}$ corresponding to 0.991 indicated a greater reliability of the experiment performed. The analysis showed that the form of the model chosen to explain the relationship between the factors and the response is correct. Further the Adj R-squared value of 0.968 was found to be very close to pre R-squared value of 0.970 and the corresponding $\mathrm{R}^{2}$ value of 0.907 indicated that the model was appropriate and can be used for the quantitative of amylase production.

Table 3: Analysis of variance (ANOVA) for response surface quadratic model obtained from experimental designs

\begin{tabular}{lllllll}
\hline Source & Sum of square & $\mathrm{df}$ & Mean square & F value & Prob $>\mathrm{F}$ & \\
\hline Block & 2.37 & 2 & 1.19 & & & \\
Model & 216.76 & 15 & 14.45 & 23.51 & $<0.0001$ & Significance \\
A & 195.50 & 1 & 195.50 & 318.09 & $<0.0001$ & \\
B & 1.15 & 1 & 1.15 & 1.88 & 0.1792 & \\
C & 0.11 & 1 & 0.11 & 0.19 & 0.669 & \\
D & 2.97 & 1 & 2.97 & 4.84 & 0.034 & \\
E & 4.24 & 1 & 4.24 & 6.89 & 0.0126 & \\
AB & 0.41 & 1 & 0.41 & 0.66 & 0.4223 & \\
AC & $4.513 \mathrm{E}-003$ & 1 & $4.513 \mathrm{E}-003$ & $7.342 \mathrm{E}-003$ & 0.9322 & \\
AD & 2.17 & 1 & 2.17 & 3.54 & 0.0681 & \\
AE & 0.016 & 1 & 0.016 & 0.026 & 0.8719 & \\
BC & 0.46 & 1 & 0.46 & 0.74 & 0.3947 & \\
BD & 0.014 & 1 & 0.014 & 0.022 & 0.8825 & \\
BE & 3.23 & 1 & 3.23 & 5.25 & 0.0279 & \\
CD & 0.022 & 1 & 0.022 & 0.036 & 0.8508 & \\
CE & 6.28 & 1 & 6.28 & 10.22 & 0.0029 & \\
DE & 0.19 & 1 & 0.19 & 0.31 & 0.5825 & \\
Residual & 22.13 & 36 & 0.61 & & & \\
Lack of Fit & 19.88 & 27 & 0.74 & 2.95 & 0.043 & \\
Pure Error & 2.24 & 9 & 0.25 & & \\
Core Total & 241.26 & 53 & & & \\
\hline Std Dev $0.78 ; R$ & & & & \\
\hline
\end{tabular}

Std Dev 0.78; R-squared 0.907; Adj-squared 0.968; CV 0.991; pred r squared 0.970 


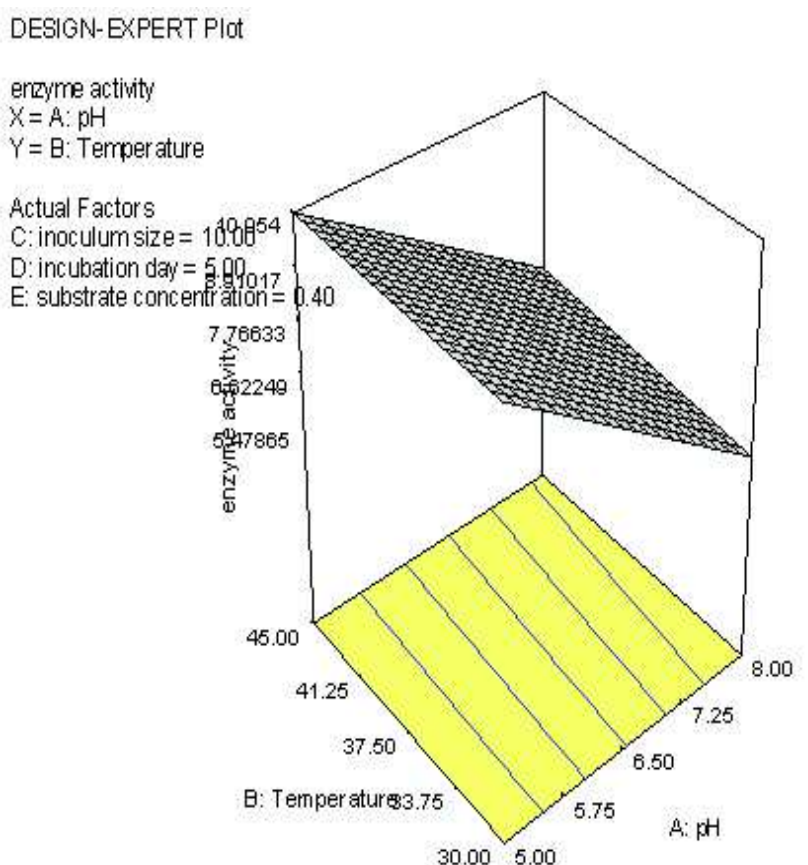

Fig. 2A: Effect of $\mathrm{pH}$ and Temperature on amylase production using B. amyloliquifaciencs SH8

\section{DESIGNEXPERT Plot}

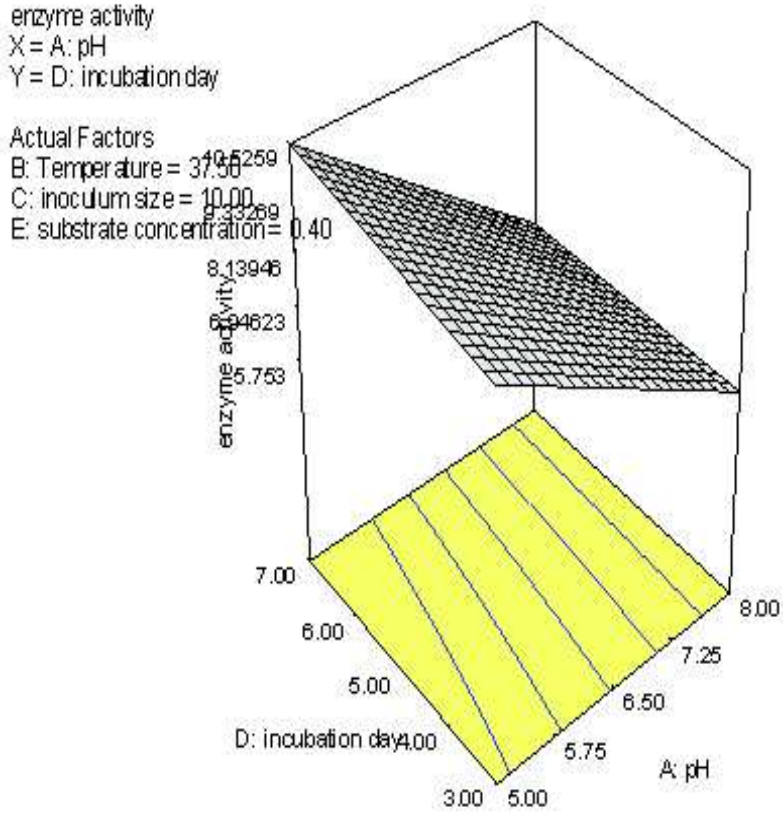

Fig. 2C: Effect of $\mathrm{pH}$ and incubation days concentration on amylase production using $B$. amyloliquifaciencs SH8

\section{DESIGN-EXPERT Plot}

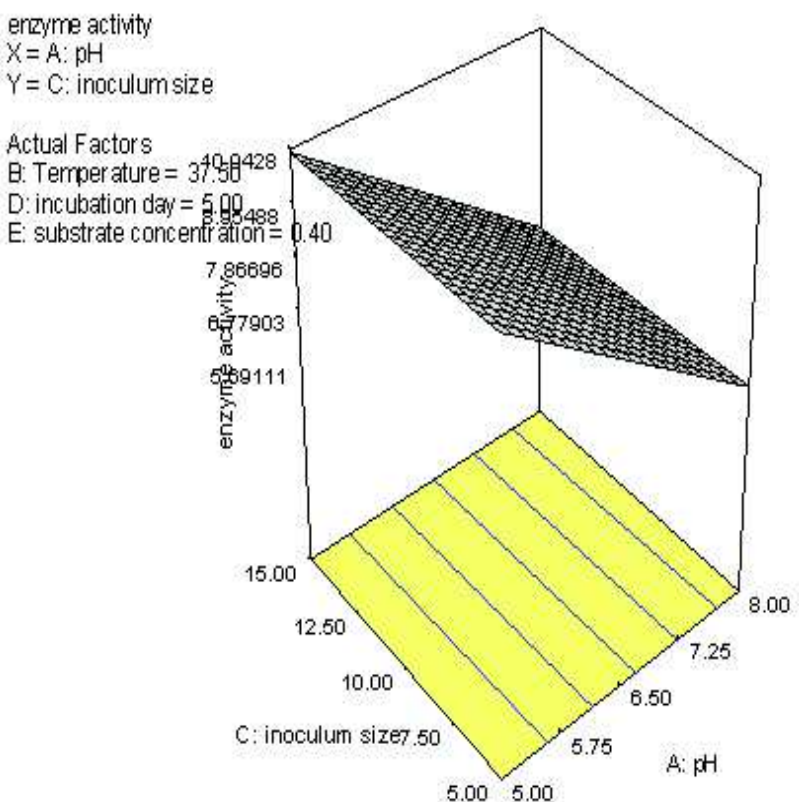

Fig. 2B: Effect of $\mathbf{p H}$ and inoculum size on amylase production using B. amyloliquifaciencs SH8

\section{DESIGN-EXPERT Plot}

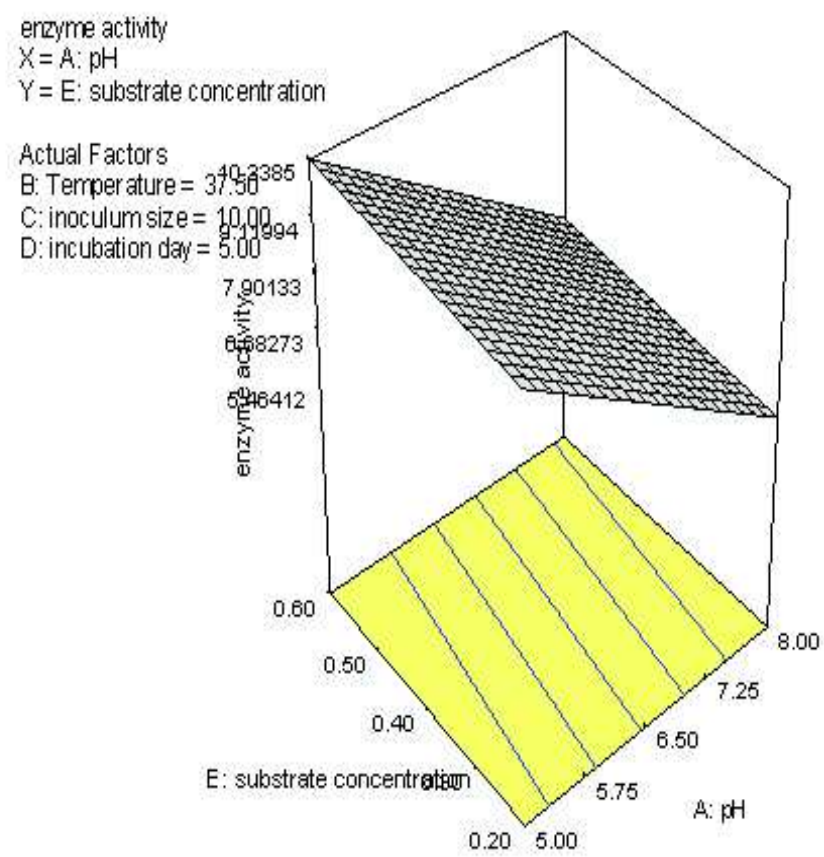

Fig. 2D: Effect of $\mathrm{pH}$ and substrate on amylase production using B. amyloliquifaciencs SH8 


\section{DESIGN-EXPERT Plot}

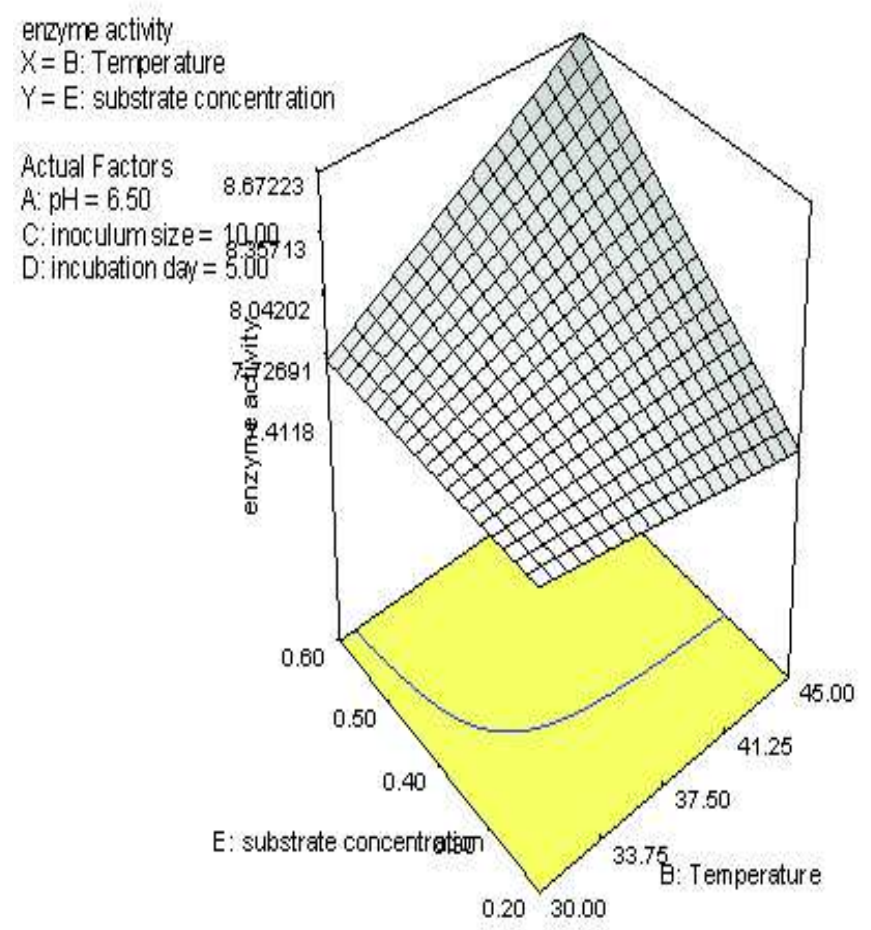

Fig. 2E: Effect of inoculum size and incubation days on amylase production using $B$. amyloliquifaciencs SH8

\section{DESIGN-EXPERT PIot}

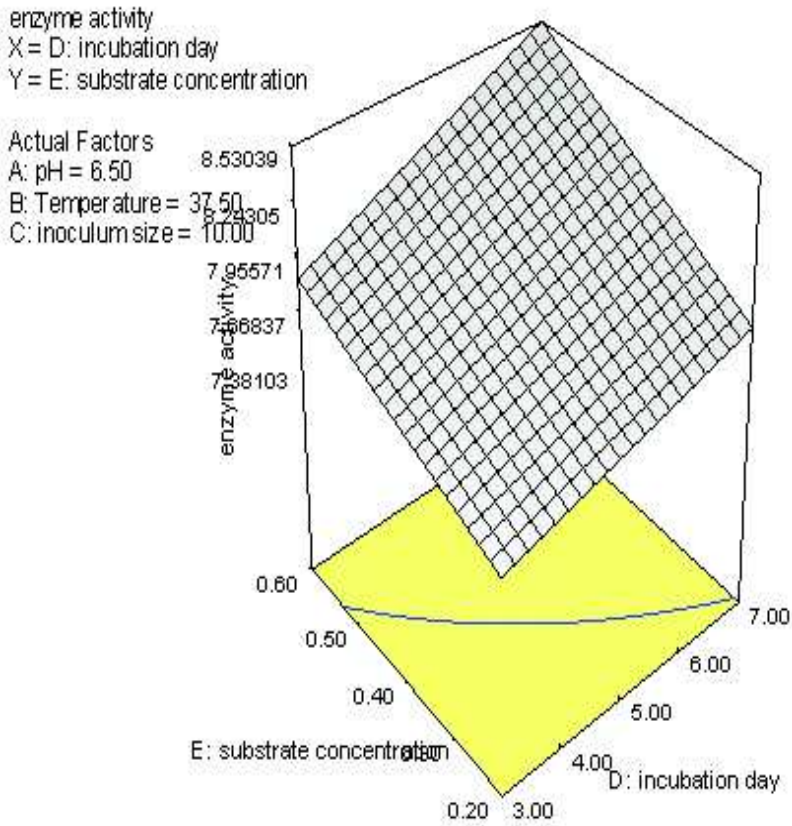

Fig. 2G: Effect of incubation days and substrate concentration on amylase production using B. amyloliquifaciencs SH8

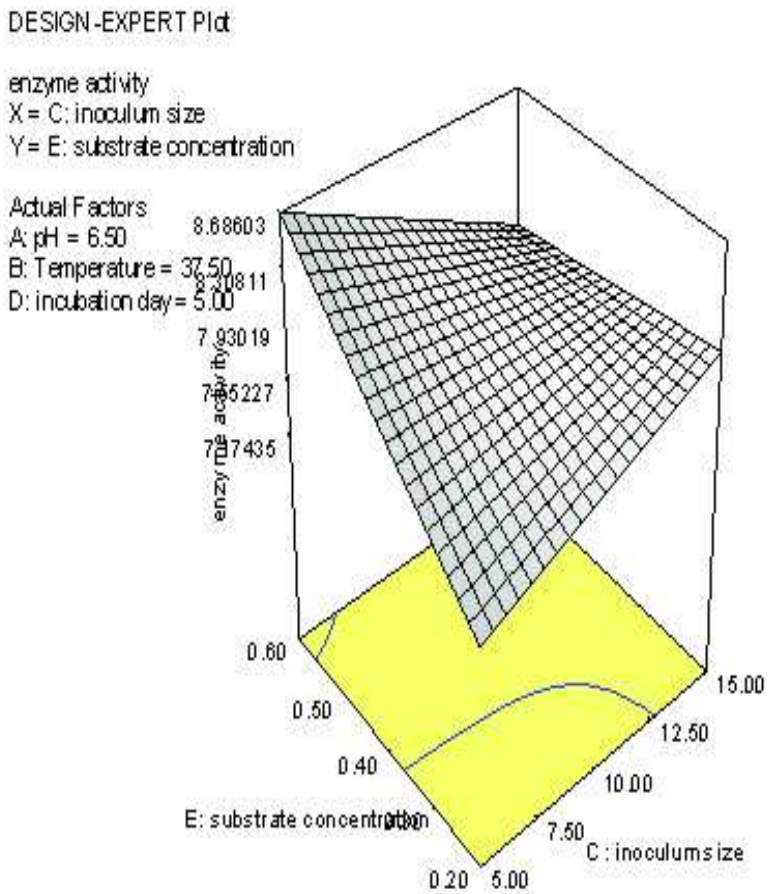

Fig. 2F: Effect of inoculum size and substrate concentration on amylase production by $B$. amyloliquifaciens SH8

\section{DESIGN-EXPERT PIot}

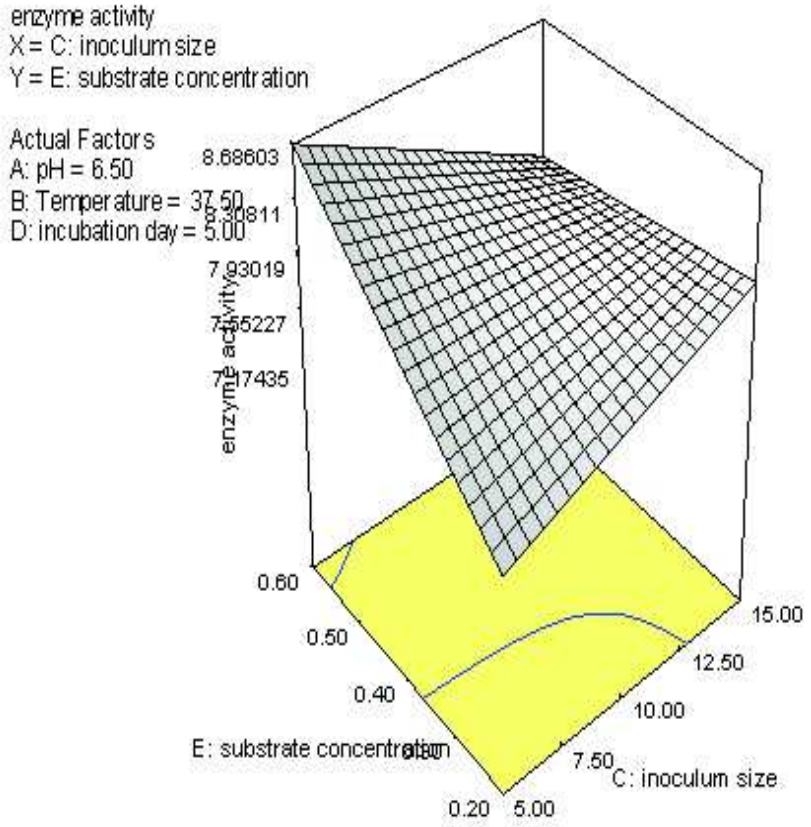

Fig. 2H: Effect of inoculum size and substrate concentration on amylase production using B. amyloliquifaciencs SH8 
Enzyme activity $=+7.88-2.1 * \mathrm{~A}+0.16 * \mathrm{~B}-$ $0.051 * \mathrm{C}+0.2 * \mathrm{D}+0.31 * \mathrm{E} \quad+0.11 * \mathrm{~A} * \mathrm{~B}-0.012$ $* \mathrm{~A} * \mathrm{C}-0.26 * \mathrm{~A} * \mathrm{D}-0.02 * \mathrm{~A} * \mathrm{E}+0.12 * \mathrm{~B} * \mathrm{C}$ $+0.021 * \mathrm{~B} * \mathrm{D}+0.32 * \mathrm{~B} * \mathrm{E}-0.026 * \mathrm{C} * \mathrm{D}-$ $0.44 * \mathrm{C} * \mathrm{E}+0.07 * \mathrm{D} * \mathrm{E}$

Table 1 gives the CCD matrix with experimental and predicted values for cellulase activity. The regression equation showed the cellulase activity as an empirical function in terms of coded factors, where $\mathrm{Yi}$ is the predicted cellulase activity in $\mathrm{U} / \mathrm{ml}$. ANOVA for response surface quadratic model gave $\mathrm{F}$ value $=$ 23.51 with pvalues of all the coefficients $(\mathrm{p}<0.0001)$, implying the significance of the model. The coefficient of variation of the model was $(\mathrm{C} . \mathrm{V}=$ The goodness of fit of the model was examined by determination coefficient $(\mathrm{R} 2=0.999)$ which implied that sample variation of more than $99.9 \%$ was attributed to the variables and only $0.1 \%$ of total variance could not be explained by the model (Haaland, 1989). The adjusted determination coefficient (Adj R2 $=0.999)$ was also satisfactory to confirm the significance of the model.

The "Pred R-Squared" of 0.741 was in reasonable agreement with the "Adj RSquared" 0.869 of. Adeq precision measured the signal to noise ratio. A ratio greater than 4 is desirable. The results of the response surface quadratic model in the form of analysis of variance (ANOVA) with significance of each coefficient, determined by student's t- test are listed in Table 2.

Response surface methodology (RSM) was used to investigate the combined effect of relevant process variables to maximize the production of xylanase in submerge fermentation by Penicilliumcitrinum MTCC 2553. The process variables include $\mathrm{pH}(6.5$, 7.0 and 7.5$)$; temperature $\left(25,30\right.$, and $\left.35^{\circ} \mathrm{C}\right)$; agitation speed (190, 200, and $210 \mathrm{rpm})$; and, substrate (xylan) concentration $(0.70 \%, 0.75 \%$, and $0.80 \%)$.

\section{References}

Azhari R and Lotan N (1991) Enzymic hydrolysis of biopolymers via single-scission attack pathways: a unified kinetic model J Mater Sci Mater Med 2 9-18

Bijttebier A, Goesaert H and Delcour J A (2007) Temperature impacts the multiple attack action of amylases Biomacro
The optimal calculated values of tested variables for maximal production of xylanase were: $\mathrm{pH} 7.49$, temperature $29^{\circ} \mathrm{C}$, agitation speed $209 \mathrm{rpm}$, and substrate concentration of $0.75 \%$ (Ghoshal et al., 2011).

Gangadharan et al., 2007) used RSM of synthesis of alpha amylase by B. amyloliquefaciens under submerged fermentation using Plackett-Burman design whichrevealed the following i.e. substrate concentration $(12.5 \%)$, incubation period $(42 \mathrm{~h})$ and $\mathrm{CaCl}_{2}(0.0275 \mathrm{M})$.

\section{Conclusion}

The present study using central composite design (CCD) of RSM is a collection of statistical techniques for designing experiments building models, evaluating the effect of factors and obtaining optimum conditions for desirable responses. Amylase activity obtained by optimizing the medium contents was found to be significantly affected by the interaction of $B$. amyloliquifaciens SH8 with the designed medium. Final optimized conditions are obtained by solving inverse matrix from the equation and through statistical analysis of the constraints. The optimum values of the tested variables were obtained using both the means with $\mathrm{pH} 5$, temperature $45^{\circ} \mathrm{C}$, inoculum size $5 \%$, after 5 days of incubation days and $0.60 \%$ of substrate concentration i.e. starch at these optimized conditions the model predicted $16.07 \mathrm{U} / \mathrm{ml}$ of amylase activity.

\section{Acknowledgements}

The financial support received from Department of Biotechnology, Govt. of India, NewDelhi, India is acknowledged.

\section{Conflict of Interest}

The authors have declared that no conflict of interest exists.

molecules 8 765-772

Blume J E and Ennis H L (1991) Adictyosteliumdiscoideum cellulase is a member of a spore germination-specific gene family J Biol Chem 266 15432-15437

Bozic N, Ruiz J, Santin J L and Vujcic Z (2011) Optimization of the growth and $\alpha$-amylase production of Bacillus subtilis 
IP 5832 in shake flask and laboratory fermenter batch cultures J Serb Chem Soc 76 965-972

Gangadharan D, Sivaramakrishan S, Nampoothiri K M, Sukamaran R K and Pandey A (2007) Response surface methododlgy for the optimization of alpha amylase production by Bacillus amyloliqufaciens Bioresour Technol 90 4597-4602

Ghoshal G, Kamble A, Shivhare U S and Banerjee U C (2007) Optimization of culture conditions for the production of xylanase in submerge fermentation by Penicilliumcitrinum using response surface methodology IJRRAS 6 132-137

Gupta R, Gigras P, Mohapatra H, Goswami V K and Chauhan B (2003) Microbial $\boldsymbol{\alpha}$-amylases: a biotechnological perspective Process Biochem 38 1599-1616

Jabasingh S A and Nachiyar C V (2010) A new combinational statistical approach for cellulase optimization in Aspergillus nidulans Indian Journal of Science and Technology 3 871-876

Kramhøft B, Bak-Jensen K, Mori H, Juge N, Nohr J and Svensson B (2005) Involvement of individual subsites and secondary substrate binding sites in multiple attack on amylase by barley $\boldsymbol{\alpha}$-amylase Biochemistry 44 1824-1832
Rezaei P S, Darzi G N and Shafaghat H (2010) Optimization of the fermentation conditions and partialcharacterization for acido-thermophilic $\boldsymbol{\alpha}$-amylase from Aspergillus niger NCIM 548 Korean J ChemEng 27 919-924

Shaw J, Lin F P, Chen S C and Chen HC (1995) Purification and properties of an extracellular maamylase from Thermus sp. Bot Bull Acad Sin 36 19-24

Svensson B, Jensen M, Mori H, Bak-Jensen K, Bonsager B, Nielsen P, Kramhøft B, Praetorius-Ibba M, Nohr J, Juge N, Greffe L, Williamson G and Driguez H (2002) Fascinating facets of function and structure of amylolytic enzymes of glycoside hydrolase family 13 Biologia Bratislava 57 5-19

Van der Maarel M J E C, Van der Veen B, Uitdehaag J C M, Leemhuis $\mathrm{H}$ and Dijkhuizen L (2002) Properties and applications of starch converting enzymes of the $\boldsymbol{\alpha}$-amylase family $J$ Biotechnol 94 137-155

Vijayalakshmi S K, Abha S and Chander P (2012) Isolation and characterization of Bacillus subtilis $\mathrm{KC} 3$ for amylolytic activity Int JBiosci Biochem Bioinform 2 336-341

Xiao Z Z, Storms R and Tsang A (2005) Microplate-based carboxymethyl-cellulose assay for endoglucanase activity Anal Biochem 342 176-178. 